\title{
POSTMODERNISTINIS VARTOTOJIŠKUMAS KAIP GENTINĖS RINKODAROS FORMAVIMOSI PRIEŽASTIS IR VYSTYMOSI TIKSLAS
}

\author{
Adomas Vincas Rakšnys, Arvydas Guogis \\ Mykolo Romerio universitetas
}

\begin{abstract}
Anotacija
Šiuolaikinèje visuomeneje pradeda tarpti naujos organizavimosi formos, kurios leidžia individams atrasti ribotą, bet vis dèlto žmogaus prigimčiai būdingą identitetą, leidžiantị siekti jeigu ir ne visuomeninio, tai bent jau grupinio bendrumo. Orientavimasis į grupes, savotiškas „gentis“, ịmanomas skatinant vartotojiškumo vertybes, kurios formuojasi kapitalizmui plečiantis ir gilëjant, nes kapitalizmas negali nesiplèsti. Postmodernizmas sudaro tą kultūrinę aplinką, kuri lemia „gentinès rinkodaros“ reiškini kaip mobilizuojanti paskiras grupes vis didesniam, kartais aiškiai išreikštam, specifiniam vartojimui. Autoriai savo straipsnyje kelia tikslą atskleisti vartotojiškumo, kaip vienos iš sudedamųjų postmodernistinès kultūros dalių, ịtaką „,gentinès rinkodaros“ formavimuisi ir atvirkštiniam šio reiškinio supratimui.
\end{abstract}

PAGRINDINIAI ŽODŽIAI: postmodernizmas, vartotojiškumas, gentinè rinkodara, privatus sektorius.

\begin{abstract}
In contemporary society the new organizational forms take pace, which enable individuums to form some kind of common identities by reaching consumers communities. Consumerism is the main feature of such communities, which may be called as certain "tribes" with their values and they develop as capitalist system deepens and widens. Postmodernism creates such cultural environment, which forms "tribal marketing" phenomena as mobilizing different groups for the more developed, clearly defined and specific consumption. The authors in the article seek to reveal the impact of postmodernist consumerism to the formation of "tribal marketing" and the development of this phenomena vice/versa.

KEY WORDS: postmodernism, consumerism, tribal marketing, private sector.
\end{abstract}

DOI: http://dx.doi.org/10.15181/tbb.v69i1.1048

\section{Ivadas}

Gausus vartojimas, tuo labiau vartotojiškumas niekad nebuvo būdingas Rytų despotijoms ar totalitariniams režimams. Pirmą kartą vartotojiškumą paminejjo ir pateikè jo kritiką Thorstein Veblen 1899 metais (Veblen, 1899 [1994]). Tačiau apie masini vartojimo didèjimą iš esmès prabilta tik pokarinèse Vakarų gerovès valstybèse - tada, kai vidutinès klasès pasiekè toki pajamų lygit, kuris leido ịsitvirtinti vartotojiškoms tendencijoms. Tuo metu Vakaruose atsirado įvairių sociologinių srovių, kurios vartotojiškumą vertino kritiškai. Labiausiai čia išsiskyrè neomarksistai su Erichu Frommu priekyje, kuris iškèlè fundamentalų klausimą: 
(angl.) “To have or to be?” (Turèti ar būti?) (Fromm, 2005). Tokia klausimo formuluotė žymèjo naujo tipo laikmetị, kai „turejjimas“ ėmè gožti „buvimo“ ar „,egzistencinius" klausimus. Šis klausimas iškeltas stipriausiame modernistinio etapo taške, kai tradicinès ūkio šakos - pramonè ir žemès ūkis pasiekẻ labai aukštą išsivystymo lygị. Galima teigti, kad vèlesnis - neoliberalizmo ir globalizacijos laikotarpis, datuojamas 9-10-uoju praejjusio amžiaus dešimtmečiais, pasižymèjo jau kitokia ūkio struktūra, būtent - paslaugų, taip pat ir sparčiai augančių finansinių paslaugų dominavimo tendencijomis, kai klausimai apie „būtị“ iškildavo tik postmodernistiniu rakursu, kuris jau nebeprimine „fromiškojo“ modernistinio laikotarpio.

Savo ruožtu Rytų Europos šalyse, kaip ir daugelyje besivystančių Azijos, Afrikos bei Lotynų Amerikos valstybių, kalbėti apie vartotojiškų tendencijų modernistini stilių nevisiškai tikslu, nes tiek komunistinėse, tiek ir liberaliose besivystančiose šalyse daugelio gyventojų pragyvenimo lygis buvo žemas, dažnai net neužtikrintos elementaraus vartojimo galimybès. Prisiminkime sovietinio „deficito“ ekonomiką, prekybą ir suprasime, kad sovietinę visuomenę vadinti vartotojiška nelabai tikslu. Tačiau potencialiai, arba susiklosčius palankesnėms aplinkybėms, sovietinès sistemos gyventojai buvo linkę ị didesnị vartojimą, kartais net vartotojiškumą, kurie tarpo šešèlinėje prekybos „blato“ ekonomikoje. Per paskutini sovietinio valdymo dešimtmeți, politinio atšilimo sąlygomis, žiniasklaida keldavo diskusijas apie ,ydingą“ socialistiniam gyvenimo būdui vartotojiškumo epidemiją. Prisiminkime, pvz., diskusijas Maskvoje leidžiamame laikraštyje „Literaturnaja gazeta“ arba Vilniuje publikuojamame intelektualų vertinamame „Literatūros ir meno" savaitraštyje.

Atkurtos nepriklausomos Lietuvos, kaip ir daugelio kitų postkomunistinių kraštų, vystymąsi per pastarajị ketvirtị amžiaus jau drąsiai galima vertinti kaip vartotojiškos visuomenės stiprèjimą, nors daugelio šių visuomenių narių pajamos vis dar neatitiko vidutinio ar net minimalaus gyvenimo lygio.

Atvira vakarietiško vartojimo sklaida per atviras sienas ir vidaus rinkų stiprejjimas per pastaruosius dvidešimt metų postkomunistinèse šalyse leidžia kalbèti ne tik apie vartojimą, bet ir apie vartotojiškumą. Rytų Europai, Rytų Azijai, Lotynų Amerikai taip pat, kaip ir Vakarų visuomenėms, jau būdinga postmodernistinè vartotojiška pasaulèžiūra, kuri individualaus pasaulio vaizdą iškelia virš sisteminio holistinio supratimo, kuriam nesvetimas ir dvasinių vertybių supratimas. Tačiau kartais šiam pasauliui būdingas ne tik individualistinis, bet ir grupinis, tam tikru identitetu pagrịstas supratimas. Šiuolaikiniam vystymosi supratimui pirmiausia būdinga ekonomizacija ir ekonominio augimo vertybès. Jos mažina socialinių-humanitarinių vertybių svarbą ir absoliutina kiekybinius rodiklius, kaip visa ko matą. Ekonomizacija persmelkia visą gyvenamają aplinką, dažnai net ir kultūrinę, kuri suponuoja ekonominio pobūdžio sprendimus politikoje, vadyboje ir administraci- 
jose. „Ekonominis žmogus“ nugali „,sociologinį žmogų“, kuriam dar taip neseniai buvo būdingas procedūrų ir taisyklių laikymasis, ir iškelia makiavelišką principą „tikslas pateisina priemones“, kuris orientuotas ị beatodairišką pajamų ar turto gausinimą, kurie savo ruožtu būtini, siekiant beatodairiškai įsigyti naujų daiktų. „Daiktai“ pradeda gožti žmones ir žmogiškumą, jiems tarnaujama kaip autoritetams ir vertybėms. Egzistencinès vertybės užleidžia vietą vartotojiškoms, kurios net ir žmones paverčia savotiškais ,daiktais“. Socialiniuose moksluose jau vartojamas komodifikacijos terminas, žymintis žmogaus ,suprekinimą“. İ dekomodifikaciją (,išprekinimą“) orientuotų politinių ar visuomeninių jègų yra vis mažiau ir jos kritikuojamos, kaip griaunančios visuomenès stabilumą, neįsiliejančios ị logišką kapitalizmo vystymosi tẻkmę. Faktiškai kūrybinè žmogiškoji prigimtis nebepripažistama pati savaime - ji pripažisstama tik tuo atveju, jeigu tarnauja ekonominio vystymosi tikslams, siekiant didesnio pelno ir dar aukštesnio vartojimo lygio.

Savo ruožtu šiuolaikinejje visuomenėje pradeda tarpti naujos organizavimosi formos, kurios padeda individams atrasti ribotą, bet žmogaus prigimčiai vis dèlto būdingą identitetą, leidžiantị siekti jei ir ne visuomeninio, tai bent jau grupinio bendrumo. Orientavimasis ị grupes, savotiškas ,gentis“, įmanomas skatinant puoselèti vartotojiškumo vertybes, kurios formuojasi kapitalizmui plečiantis ir gilejjant, nes kapitalizmas negali nesiplèsti. Postmodernizmas sudaro tą kultūrinę aplinką, kuri formuoja „gentinès rinkodaros“ reiškinị kaip mobilizuojantị paskiras grupes vis didesniam, kartais aiškiai išreikštam, specifiniam vartojimui. Autoriai savo straipsnyje kelia tikslą atskleisti vartotojiškumo, kaip vienos iš sudedamujų postmodernistinès kultūros dalių, ịtaką „,gentinès rinkodaros“ formavimuisi ir atvirkštiniam šio reiškinio supratimui. Savo tikslui pasiekti autoriai taiko aprašomaji, sisteminės kritinès ir palyginamosios analizès metodus.

\section{Postmoderni visuomenė - vartotojiškumo evoliucijos niša}

Kiekvienam istoriniam etapui būdinga tam tikra unikalių kultūrinių idèjų, vertybių ir gyvenimo formų visuma, kurios neišvengiamai persismelkia per visus visuomenès klodus, valstybines institucijas, privataus sektoriaus organizacijas ir pavienių individų sąmonès struktūras. Postmodernizmo epocha - tai opozicija modernistinèms vertybėms, realizmui, vientisumui, sintezei, racionalumui, optimizmui, stabilumui, vartojimui, universalizmui, aiškumui, identitetui, elitui (autoritetui). Analizuojant jos anatomiją pastebètina, kad ịsivyrauja masinė kultūra ir fragmentacija, demontavimas, anarchija, tiesos pliuralizmas, autoritetų erozija, hedonizmas, identiteto krize, simuliacijos ir tinklaveika, beprasmybè, cinizmas, visuotinis netikrumas, vartotojiškumas, reliatyvizmas, situacinè etika, subjekty- 
vios interpretacinès elgsenos, nuolatiniai pokyčiai ir laikinumas (Burbach, 2001, p. 69; Rojek, 1995, p. 129; King, 2005; Hassan, 2001, p. 121). Be abejo, šie epochos simptomai daugelyje gyvenimo sričių priverčia kelti klausimą, kaip tinkamai derètų reaguoti postmodernizmo akivaizdoje? Ar postmodernizmo bruožai yra realios grèsmès tolesnei šiuolaikinès civilizacijos egzistencijai, kurias būtina įvertinti? O gal intelektinès refleksijos galètų padèti išnaudoti ši postmodernistinès minties judesio skverbimąsi, jị neutralizuojant ar net nukreipiant konstruktyvia linkme? Ad hoc, autoriai išsikèlè tikslą panagrinèti privataus sektoriaus organizacinę patirti, šiuolaikiniame vadybos diskurse aktualią ,gentinès rinkodaros“ strategiją (angl. tribal marketing), kuri įformina daugeli aptartų postmodernios visuomenès bruožų, verslo atžvilgiu juos nukreipiant pačia konstruktyviausia linkme - pelno maksimizavimo link.

Privatus sektorius, paisydamas postmodernistinių tendencijų, igyvendina savo tikslus, kurdamas vartotojišką bendruomenę (bendruomenę, kurios nariai jai nepriklausydami pasižymi identiteto stoka, jaučiasi atomizuoti ir fragmentuoti beveidès visuomenès elementai, kuriuos kamuoja beprasmybès jausmas, savirealizacijos trūkumas ir individualizmas, jų socialinè interakcija apribota šiuolaikinių technologiju ir simuliacijų, kurių motyvaciniai stimulai apsiriboja hedonistinių poreikių tenkinimu) (Cova, Cova, 2002, p. 596-597). Kita vertus, galimas atvejis, kad verslas išnaudoja esamą bendruomenę (jų kolektyvines emocijas ir poreikius), susibūrusią apie konkrečią veiklą (pavyzdžiui, sporto komandos), ir, naudodamasis postmoderniais instrumentais (simboliais, simuliacijomis, masine atributika), stengiasi sužadinti jų vartotojiškumą, orientuojantis ị tokius žmogiškus veiksnius, kaip noras išsiskirti ar pabrēžti savo unikalumą, santykį, hierarchinę poziciją bendruomeneje (Meir, Scott, 2007, p. 331-333).

Būtina pabrèžti, nors straipsnio autorių dèmesio ir patirties laukas yra viešojo valdymo modernizavimo problematika, tačiau atsižvelgiant $\mathfrak{i}$ augančią viešojo ir privataus sektoriaus partnerystès plètrą negalima ignoruoti galimybės išnaudoti gerają verslo patirtį, tinkamai integruojant neigiamas postmodernizmo kultūrinès dimensijos įtakas (arba bent jau jas neutralizuojant). Todèl „gentinès rinkodaros“ analizė galètų tapti argumentu, kodèl postmoderniame valdyme (ypač besiformuojančio naujojo viešojo valdymo kontekste) būtina iš naujo įvertinti komunitarizmą. „Gentinès rinkodaros" analizè gali būti naudinga ir akademiniuose debatuose dèl postmodernios epochos genezès, kol tam tikri intelektiniai sluoksniai ją neigia. Šis pavyzdys atskleidžia, kaip laiku, atsižvelgiant ị šiuolaikinius kultūrinius veiksnius, galima sukurti kokybišką ir funkcionalų teorinị modelị ar strategiją, atspindinčią epochos charakteristikas.

Prieš pradedant nagrinèti ,gentinès rinkodaros“" sampratą, pravartu išsiaiškinti, kuo skiriasi moderni (modernizmo) ir šiuolaikinė postmoderni visuomenès. Pasi- 
telksime sociologo Z. Baumano įžvalgą. Z. Baumano (2004, p. 24) teigimu, modernizmo visuomenès narius siejo industriniai ryšiai, socialinè struktūra ir normos buvo orientuotos ị tai, kad individas galètų šias funkcijas atlikti. Šiuolaikinejje postmodernioje visuomenèje tas spaudimas išliko, tik dabar individas turi būti nebe gamintojas, o vartotojiškumo objektas. Vartotojiškos visuomenès ịsigalèjimui postmodernioje epochoje linkę pritarti ir kiti autoriai. Kaip teigia R. K. Payne (2010, p. 43), vartotojiška visuomenė apibūdinama atsižvelgiant ị tai, kaip ji panaudoja savo laisvą laiką, leisdama pinigus (apsipirkinėdama, keliaudama, pramogaudama), ir koks jos tikèjimas (pirminis kelias ị laimę yra tam tikrų daiktų turèjimas, kuris neišvengiamai tampa gyvenimo tikslu). J. O'Shaughnessy ir N. J. O'Shaughnessy (2002, p. 525) tai konkretizuoja aiškindami, kad vartotojišką visuomenę geriausiai apibūdina poreikis masiškai kaupti ir naudoti materialius daiktus, kuris nulemtas individualaus hedonizmo. Taigi, remdamiesi minètų autorių mintimis, turime pastebèti, kad ekonominiu, sociologiniu ir psichologiniu aspektais šiuolaikinès visuomenès motyvacinėmis gyvenimo ir mąstymo formomis tampa infliacinis, materializmo kultas, pagristas individualių malonumų poreikiu. Šios vartotojiškos laikysenos yra tarsi reakcija ị epochos keliamus iššūkius: identiteto krizę, nykstančias tradicines vertybes, visuomenès klasių ir praeities ịtaką, laikinumą, augantị technologijų vaidmenį, silpnèjančią ištikimybę ir trumpejjantị laiko supratimą, kas lemia dabarties momento suabsoliutinimą ir esamos akimirkos intensyvumo maksimizavimą (Dunn, 1998, p. 12; Francese, 1997, p. 3).

Tačiau postmoderni epocha paradoksali tuo, kad ne tik fragmentuoja ir atomizuoja visuomenès narius, čia pastebimas ir individų poreikis atrasti pakaitalą tradicinèms visuomenès struktūroms (modernistinèmis ir ikimodernistinėmis vertybėmis pasižymejjusioms bendruomenėms) ir anksčiau jų teiktiems ryšiams, kurie šiuo metu sunykę. Taigi šiuolaikinèje visuomenejje išryškejja tam tikri demontavimo aspektai, kai restruktūrizuojant esamas visuomenès sistemas bandoma sukurti naujas, pasižyminčias postmoderniais elementais (ypač vartotojiškumu). Kaip ši procesą apibūdina M. Patterson (1998, p. 71), naujosios gentys (arba vartotojiškos bendruomenès - aut.) pasitelkia vartotojiškumą, kaip tam tikrus „socialinius klijus“, kurie pakeičia tradicinius socialinius institutus - religiją ar šeimą, suburdavusius žmones. Tai reiškia, kad dèl silpnėjančių tradicinių institutų susidariusią nišą pamažu užpildo naujos vartotojiškos bendruomenès, kurios ne tik deformuoja tradicinę bendruomenès sampratą, bet ir didina individualų vartotojiškumo poreikị. Kitaip tariant, individualus vartotojiškumas postmodernios bendruomenès kontekste evoliucionuoja ị kolektyvinę ir daug intensyvesnę formą. Tačiau akivaizdu, kad nykstantys tradiciniai institutai ir poreikis juos kuo nors pakeisti nèra vienintelè šio reiškinio priežastis. 
Kaip minèta, silpstančios vertybės, tradiciniai sampratos konstruktai, įsivyraujantis multikultūralizmas tampa iššūkiu žmogaus identitetui. Jeigu nebėra jokių pastovių struktūrų, normatyvinių konstruktų, ì kuriuos galima būtų lygiuotis, o aplinka nuolat ir sparčiai kinta, kaip žmogui susivokti, kas jis yra? Kaip išvengti visuomenès izoliacijos, atrasti save ir pritapti prie kitų? Kaip tapti savu šioje sumaišties epochoje? Juk žmogaus poreikis priklausyti grupei ar visuomenei pasižymi evoliucine, imperatyvia logika. Atsakymą į šiuos klausimus suteikia vartotojiškos bendruomenès. Siekiant tapti bendruomenès nariu, dalị tapatinimosi su grupe proceso apima ịvairūs ritualai, kaip rinkimas, keliavimas, gebejjimas pasirinktą bendruomenę traktuoti kaip dalị savęs, savojo identiteto. Paklusimas vartotojiškai logikai tampa integracijos dalimi. Individai igauna pasitikejimą ir stiprina savaji identitetą dèl vartotojiškų ryšių su šiomis bendruomenèmis (Dionisio ir kt., 2008, p. 20). Taigi, atsižvelgiant ị platų prekių ar paslaugų, kurioms galima „atsiduoti“, diapazoną, individas tiesiog privalo užsiimti vartotojiška veikla, taip automatiškai išvengs socialinės izoliacijos ir taps visuomenès bei, atsižvelgiant ị turimus finansinius pajègumus, konkrečios vartotojiškos bendruomenès dalimi.

Kitas svarbus aspektas yra šiuolaikinių technologijų ir masinès medijos vaidmuo. Ji skatina ir ịaudrina individų fantaziją bei skatina poreikị atsiduoti vartotojiškumui, reklamuodama tam tikrus prekių ženklus ar apie juos susibūrusias bendruomenes (Dunn, 1998, p. 12). Kaip šią tendenciją apibūdina S. Boden (2003, p. 6), postmodernioje epochoje išryškejja takoskyra tarp simbolio ir realaus produkto. Prekès ar paslaugos tampa vertingos ir ịsigyjamos dèl jų ženklo žinomumo. Materialistinis simbolių ,apsẻdimas“ tampa varomaja postmodernios vartotojiškos visuomenès jẻga. Daiktų sureikšminimas formuoja naują dialogo formą, kuri užmezgama šiame procese ir leidžia išreikšti savajj identitetą. Tačiau papildant autoriaus mintị, būtina pastebèti, kad greta ženklo žinomumo ir galimybės su juo susitapatinti pastebimos ir vartojimo infliacijos tendencijos, kitaip tariant, kiekybinių aspektų hiperbolizavimas. Šią idèją aiškiai ir paprastai apibendrino A. A. Berger (2011, p. 56). Jo teigimu, vartotojiškoje kultūroje žmonès žaidžia žaidimą kuo daugiau pirkti. Sèkmingas individas yra tas, kuris turi daugiausiai daiktų. Turime pastebèti, kad ši kiekybinè logika yra tarpdisciplininis fenomenas, pavyzdžiui, ji atsiskleidžia ir šiuolaikiniuose socialiniuose tinkluose, kai žmogus tampa žinomas dèl to, kad daugybe žmonių jị „seka“ arba ịtraukia ị savo kontaktų sąrašą. Kuo daugiau „draugų“ jis turi, tuo didesnè tikimybe individui tapti žinomam ir sèkmingam. Paradoksalu, tačiau apie tokius asmenis kartais net susiformuoja vartotojiškos bendruomenès, kurios naudojasi nuolat atnaujinama paskyros informacija, keičiasi nuomonemis, patiria intensyvias kolektyvines emocijas, gaunamas iš vartojimo objekto. Lietuvoje tai būtų viešojoje erdvejje populiarus Monikos Šalčiūtès fenomenas. Matyt, ịdomiausiu pasauliniu postmodernizmo atitikmeniu galima 
laikyti medijose pasirodžiusị „,pikto katino“ atvaizdą, kuris per porą metų sugebėjo „sugeneruoti“ $240 \mathrm{mln}$. dolerių. „Pikto katino“ reklaminis biudžetas prilygsta, pvz., visam Vanuatu šalies, esančios Ramiajame vandenyne, ar trečdaliui Džibučio valstybės, esančios Rytų Afrikoje, nacionalinio biudžeto.

Postmodernių vartotojiškų bendruomenių atsiradimo priežastis gali būti ir žmonių patiriamos emocijos. Teigiamos emocijos, pasitenkinimas savimi, gaunamas iš vartotojiškos veiklos, labai motyvuoja. Emocijos dar stipresnès, kai jų šaltinis yra kolektyvinis, o vartojant ar naudojant tą pačią produkciją, minios psichologijai veikiant stiprèja ir grupinis bendrumo jausmas. Svarbu suvokti, kad nuolat sąveikaudami šie pojūčiai tampa užkrečiami (Mitchell, Imrie, 2011, p. 40-41). Todèl jie ne tik skatina vidinių grupès narių vartotojiškumą, bet ir padeda pritraukti naujų narių iš išorès, kurie, norẻdami sėkmingai vartotojiškai save realizuoti, negali atsispirti šiai imperatyviai veiklai.

Šių unikalių bendruomenių patrauklumas akivaizdus ir analizuojant globalias postmodernios epochos transformacijas. Prancūzų intelektinès minties atstovas J. F. Lyotard (1993, p. 6) postmodernizmą vertina kaip erą, kurioje nebepasitikima „metanaratyvais“. Didžiosios modernizmo universaliosios teorijos šioje epochoje praranda turètas pozicijas. Daugiau nebėra objektyvių standartų ir vienos ontologiškai nepajudinamai įtvirtintos tiesos. Postmodernizme, kadangi visas socialinis patyrimas įtvirtinamas viename iš naratyvų, istorija, kuri socialinès grupès konstruojama apie gyvenimą ir jo sąlygas bei reikalavimus, tampa socialine realybe ir tiesa, nes né vienas naratyvas šioje epochoje neturi privilegijuoto statuso (Fuat ir kt., 1997, p. 188). Todèl, net jeigu šioje epochoje neįmanoma pasiekti universalios tiesos, vartotojiška bendruomene gali padèti atrasti lokalią tiesą (Murphy, 1989; Gómez-Arias, Acebrón, 2001, p. 14-15).

İvertinus daugelị šios postmodernios visuomenès aspektų, siekiant apibendrinti, paaiškejo, kad šiuolaikinè visuomenè, priešingai nei modernistinè ir industrinè, yra vartotojiška visuomenè, kurios socialinis spaudimas individą skatina užsiimti vartotojiška veikla. Prielaidas vartotojiškumui ịsigalèti sudaro bendras visuomenès spaudimas, problemos, susijusios su identiteto krize, vertybine degradacija, modernistinių ateities perspektyvų atsisakymu, kuris lemia dabarties momento suabsoliutinimą ir jo patyrimo intensyvumo skatinimą. Šiuos procesus ypač stiprina didejjantis technologinių komunikacijų vaidmuo. Todèl susiklosto situacija, kai vartotojiškoje visuomeneje pagrindinè gyvenimo motyvacijos forma tampa materialių daiktų kiekybinis maksimizavimas, socialinių ryšių konstravimas pagal prekès simbolius. Modernizmo epochoje socialinė individų jungtis buvo religija ar šeima, o postmodernioje epochoje ši vaidmeni perima vartotojiška bendruomenè. Akcentuotina ir tai, kad pats vartotojiškumas bendruomenejje evoliucionuoja, stiprèja jo proceso raiška, nes individų grupejje, kurią vienija kolektyvinis tos pačios 
produkcijos vartojimas, jis intensyvejja. Kiekvienas nori įrodyti, kad jo didesnès vartotojiškos galios, taip stiprinamas savasis identitetas, be to, bendruomeneje atsiranda galimybė dalintis emocijomis, kurias lemia vartotojiškumas. Ši veikla bendruomenès kontekste taip pat užtikrina esamų ryšiu stiprinimą, individualią pagarbą (atsižvelgiant ị vartojimo pajėgumą) ir naujų ryšių atsiradimą, taip vengiant socialinès izoliacijos. Svarbu ir tai, kad postmoderni bendruomenè netikrumo ir sumaišties epochoje, kur nebèra vienos universalios tiesos, tampa instrumentu atrandant lokalią tiesą, kuri dažniausiai pasižymi vartotojišku imperatyvu.

\section{Gentinė rinkodara kaip postmodernios kultūros instrumentas}

Atskleidus esmines šiuolaikinès visuomenès vartotojiškas charakteristikas ir individualias bei kolektyvines vartotojiškumo motyvacijas, būtina aptarti priemones, kurias privatus sektorius naudoja, noredamas patenkinti savo interesus, ir ši procesą intensyvina, pasitelkdamas gentinès rinkodaros strategiją. Atsižvelgiant $\mathfrak{i}$ pirmoje straipsnio dalyje aptartas vartotojiškas mąstymo ir gyvenimo formas, būtina akcentuoti, kad rinkodaros diskurse transformuojasi tradicinis supratimas apie pirkėją, paslaugų vartotoją, kaip uždarą, individualų objektą, kurio suinteresuotumas vartoti priklauso nuo prekès naudingumo ar kokybės. Postmoderni vartotojiškos kultūros teorija meta iššūki šiai tradicinei sampratai ir ị pirkejjus pradedama orientuotis kaip i jų grupes, gentis, bendruomenes, kurios buriasi apie jų teikiamą paslaugą ar produkciją (arba ieškoma, kaip šias bendruomenes suburti ar išnaudoti jau esamas, ị jas nukreipiant savo produkciją) (Goulding et al., 2013, p. 813-814; Dionisio, et al., 2008, p. 21). Viena vertus, akivaizdu, kad vartotojiškumo nukreipimas nuo vieno asmens ị grupę garantuoja geresnius kiekybinius, finansinius rezultatus, kita vertus, straipsnio autoriai siekia atkreipti dèmesị ị tai, kad yra ir kitų gentinès rinkodaros taikymo privalumų.

Pirmasis veiksnys susijęs su didejjančiu vartotojiškų bendruomenių (genčių) lojalumu parduodamai produkcijai. Daugelio autorių (Cova, Cova, 2002; Mitchell, Imrie, 2011, p. 40-41; Canniford, 2011, p. 592; Simmons, 2008, p. 303) teigimu, taikant gentinę rinkodarą stengiamasi ne tik išnaudoti didesnius vartotojiškų bendruomenių utilizavimo pajejumus, bet ir jas integruoti ị bendrą produkcijos sistemą, taip užtikrinant šių bendruomenių ilgalaikị lojalumą. Vartotojiškos bendruomenès, taikydamos šiuolaikines technologijas ir tinklaveikos metodus, gali suteikti objektyvų, grịžtamajị ryši (atsižvelgiant ị tai, kad jų pačiu identitetas ir prestižas neatsiejamas nuo šios paslaugos ar prekès) vertinti ir tikrinti produkciją, taip bendradarbiaujant su jas teikiančiomis organizacijomis. Konkretus ir sẻkmingas šių lojalių bendruomenių išnaudojimo pavyzdys galètų būti „Apple“ kompanija arba motociklų gamintojai „Ducati“. Pastarųjų vadybos modelis nulèmé ypatingą kom- 
panijos sèkmę: šiandien „Ducati“ yra ne tik populiariausias Europos motociklų gamintojas, bet ir kultinis prekès ženklas su nuolat augančia sekejjų, kurie vadinami „ducatistais“, bendruomene. Šiame modelyje tiek darbuotojai, tiek vartotojai turi tą patị statusą, kuris susijęs su prekès ženklo bendruomene. Kitaip tariant, jie neatskiriami tol, kol šiai bendruomenei priklauso. „Ducati“ ir „ducatistai“ reprezentuoja klasikini pavyzdį, kaip prekès ženklo sutelktos bendruomenės sukuria vartotojų ir gamintojų ryši, jas paverčiant tikrais kompanijos partneriais (Cova, Saucet, 2014, p. 14). Be lojalumo, reikia paminèti ir tam tikras šių bendruomenių teikiamas išorines - reprezentacijos funkcijas. Bendruomenès masiškumas, reprezentacinè, arba identifikacine, išvaizda tarnauja kaip nemokama reklama, kuri gali prisidèti prie naujų vartotojiškumo objektų paieškos.

Kitas svarbus aspektas - verslui orientuojantis ị vartotojiškas bendruomenes atsiranda galimybė plèsti paslaugų spektrą, siekiant patenkinti vidinius šių ,genčių“ psichologinius, narcistinius, saviidentifikacijos poreikius ir ritualus, kurie pasireiškia ịvairių simbolių bei ženklų demonstravimu. Šie procesai ypač aktualūs taikant gentinę rinkodarą jau apie tam tikrą veiklos šaką susiformavusioje bendruomenèje, kaip, pavyzdžiui, jau minètos sporto komandos fanų klubo atveju, ku stengiamasi išnaudoti šios ,genties“ vartotojiškumą (Meir, Scott, 2007, p. 331). Konkreti simbolika ne tik stiprina vidinius genties ryšius, bendrumo pojūtį, bet patenkina ir kitą vartotojiškumo aspektą - galimybę individus skirstyti ị savus ir svetimus (ị tuos, kurie priklauso bendruomenei ir savo statusą išreiškia vartotojiškais simboliais, ir tuos, kurie nepasižymi jokiais simboliais, kitaip tariant, socialiai izoliuotus ir nesėkmingus asmenis bei opozicinès genties simboliais pasižyminčius individus, kurie natūraliai laikytini ,svetimais“). Taigi vartotojiškoje kultūroje individai ne tik stengiasi išsiskirti visuomeneje, bet ir „savoje“ gentyje siekia pasižymèti skirtingais atributais, kurie, pavyzdžiui, sporto komandos atveju, taptų jų emocinio prisirišimo prie komandos ir vidinio statuso, hierarchijos išraiškos elementais gentyje. Čia būtina paminèti K. Hunt klasifikaciją: laikini sirgaliai (fanai), vietiniai sirgaliai, pasiaukojantys sirgaliai, sirgaliai fanatikai ir disfunkciniai sirgaliai (Hunt et al. 1999; Garry, 2008, et al., p. 961). Tokia sirgalių klasifikacija implikuoja tai, kad jie turi pasižymėti tam tikra unikalia simbolika, kuri pabrèžtų jų statusą tiek tarp vidinių genties narių, tiek tarp išorinių, opozicinių genčių. Taigi šios simbolikos gamyba tampa verslo organizacijų pajamų generavimo šaltiniu, taigi ir prioritetiniu tikslu.

Trečias veiksnys, kurị straipsnio autoriai norètų išskirti, susijęs su bendrais visuomenès struktūros pokyčiais, kurie sudaro tinkamas sąlygas taikyti gentinę rinkodarą. Atsižvelgiant ị istorinị kontekstą akivaizdu, kad modernizmo visuomené buvo industrinė visuomenė, kurios pamatinėmis vertybėmis tapo individualizmas ir arši konkurencija, o dabartiné postmoderni visuomenė yra vartotojiška, inflia- 
cinė visuomené, kurioje vartotojiškumas nebeturi ribų, nes prekės ar paslaugos ịsigyjamos ne dèl savo kokybinių charakteristikų, bet labiau dẻl estetinių bruožų ar dèl sukeliamų emocijų, įspūdžių, vaizdinių poveikio (Hjorth, Kostera, 2007, p. 117). Todẻl šiuolaikinèje rinkodaroje konkurencija nebe tokia ryški, nes postmodernūs vartotojai gali priklausyti daugeliui genčių vienu metu. B. Cova ir M. Cova (2002, p. 602) teigimu, postmodernios, vartotojiškos bendruomenès (gentys) unikalios tuo, kad ne tik ịkūnija individo psichologini priklausymo poreikị, sukuriant atitinkamą identiteto, ryšių, bendrų interesų lauką, bet ir yra atviros savo narių galimybei priklausyti daugeliui bendruomenių vienu metu. Ši autorių pozicija ịformina ir kitus du ryškius postmodernios eros bruožus - reliatyvizmą ir pliuralizmą, kai vienu metu gali egzistuoti daugybé vienodų tiesų, šiuo atveju bendruomenių, kurių produkcija, reprezentuojami prekès ženklai ar paslaugos bus vienodai „teisingi“ ir patrauklūs. Kadangi vartotojiškumo neriboja kiekybiniai aspektai - tik finansinès ir žmogaus egzistencinès galimybès, šis procesas gali trukti nuolat, taip privataus sektoriaus organizacijoms sudarant galimybę visada realizuoti savo produkciją vartotojiškų bendruomenių kontekste.

Aptarus esminius vartotojiškos visuomenės aspektus ir gentinės rinkodaros logiką, svarbu galutinai apibrèžti, kokius reikalavimus organizacijos privalo tenkinti, kad sukurtų vartotojišką (gentį), postmodernią bendruomenę, ị kurią būtų galima nukreipti savo produkciją. Akademiniame diskurse yra ịvairių rekomendacijų, straipsnio autoriai pasirinko B. Deutsch siūlomus principus, kurie, jų manymu, aiškiausiai įformina gentinès rinkodaros koncepciją:

- Netikètas atsiradimas. Būtina ideologija, kuri prieštarautų vyraujančioms normoms, ịkūnijanti bekompromisį idealizmą ir užtikrintumą, išreiškiama su romantine aistra ir šalta logika.

- Tikejjimas visuma. Mitai apie tai, kaip veikia pasaulis ir kaip bendruomenès nariai galètų maksimizuoti bei išreikšti save santykyje su pasauliu.

- Ritualai. Būtina sukurti stilizuotus, glaustus, rutinizuotus elgesio modelius, kurie atskleistų „genties“ ideologiją ir tikèjimų sistemą. Tai padètų sukurti institucijos atmintị ir skatintų jausmą, kad tu jai priklausai, dar prieš tau tampant jos nariu.

- Savita simbolika. Emblemos ir ženklai gali padèti išreikšti narystę.

- Priklausymo ir nepriklausymo grupei akcentavimas. Tai tam tikra strategija, siekianti pabrèžti savus ir svetimus, kitaip tariant, motyvuoti tapti postmodernios bendruomenès, kuri sudaro galimybę igyti galios ir save realizuoti, pasitelkus vartotojiškus instrumentus, nariu (Deutsch, 2011, p. 4).

Apibendrinant būtina pastebèti, kad gentinè rinkodara yra konstruktyvus pavyzdys, kaip kultūrinius pokyčius galima pakreipti teigiama linkme, suformuojant 
teorines konstrukcijas, kurios atitinka laiko dvasią. Gentinè rinkodara ịformina tai, kad privatus sektorius, atsižvelgdamas ị postmodernias vartotojiškas tendencijas, virtualius tinklus, visuomenès fragmentaciją, nepasitikèjimą, netikrumą ir hedonizmą, kuria rinkodaros strategiją, nukreiptą ị bendruomenès telkimą apie jų tiekiamą produkciją ar teikiamą paslaugą. Arba produkcija orientuojama ị esamą bendruomenę. Taikant pastarają strategiją stengiamasi visuomenèje vyraujantị psichologinị netikrumą, identiteto paieškas, poreikị pabrěžti savo statusą, užmegzti ir formuoti daiktinį, materialinèmis gèrybėmis paremtą „dialogą“, nukreipti verslui palankia finansine linkme. Todèl vartotojiškoje bendruomenèje rekomenduojama sukurti savitą, tikejjimu paremtą visumą, ideologiją ir vartotojiškumo ritualus. Gentinès rinkodaros taikymas privačiam sektoriui svarbus ne tik dèl tiesioginès finansinès naudos, bet ir dẻl to, kad sukuriama postmoderni bendruomenè, organizacijos užsitikrina lojalių vartotojų ratą, kurie ịtraukiami ne tik ị produkcijos realizavimo, bet ir i jos vertinimo, grịžtamojo ryšio procesus. Šios vartotojiškos bendruomenès (gentys) tampa organizaciju partneriais. Jos atlieka ir reprezentacines funkcijas, kurios skatina naujus individus įsitraukti ị vartojimo ciklą, taip atlikdamos reklamuotojos funkciją.

\section{Išvados}

1. Postmoderni visuomenė yra vartotojiška visuomene, kurioje ryškus hedonistinis, kiekybinis, materialinių gerybių kaupimo kultas. Šie aspektai laikytini reakcija ị šiuolaikinès epochos keliamus iššūkius: identiteto krizè, nykstančios tradicinès vertybès, visuomenès klasės ir praeities įtaka, laikinumas, didejjantis technologijų vaidmuo, silpnejjančios ištikimybès formos ir trumpejantis laiko suvokimas, kuris lemia dabarties momento suabsoliutinimą ir esamos akimirkos intensyvumo maksimizavimą.

2. Postmodernizme pastebimi ne tik visuomenę fragmentuojantys veiksniai, bet ir demontavimo tendencijos, kai nykstančių tradicinių institutų, kaip religija ir šeima, vaidmeni, jų puoselëjamus ryšius keičia vartotojiškos bendruomenės (gentys). Jų kontekste individualus vartotojiškumas evoliucionuoja ị daug intensyvesnę bendruomeninę stadiją.

3. Vartotojiškos bendruomenès (gentys) individui suteikia galimybę stiprinti savajji identitetą (susitapatinant su konkrečia grupe, jos atstovaujamu prekès ženklu). Be to, atsiranda galimybė save realizuoti, atsiduodant vartotojiškumo imperatyvui, ir taip išvengti socialinès izoliacijos, turint omenyje tai, kad daiktų sureikšminimas formuoja naują dialogo formą, kuri užmezgama vartojimo procese. Genčiai vartojant tą produkciją, pa- 
sitenkinimas savimi stiprina emocijas, kartu didina ir grupinị bendrumo jausmą.

4. Gentinè rinkodara orientuota ị vartotojiškos bendruomenès sukūrimą ir jos kolektyvinio vartotojiškumo maksimizavimą. Šios bendruomenès užtikrina ilgalaikị lojalumą, grižtamajji ryšį produkcijos vertinimo požiūriu, tampa reprezentaciniu, reklaminiu elementu, kuris padeda plèsti vartojimo objektų ratą. Kitas galimas atvejis - verslas išnaudoja esamą bendruomenę (jų kolektyvines emocijas ir poreikius), susibūrusią apie konkrečią veiklą (pavyzdžiui, sporto komandos), ir naudodamas postmodernius instrumentus (simbolius, simuliacijas, masinę atributiką) stengiasi sužadinti vartotojiškumą, orientuodamasis ị tokius žmogiškus veiksnius, kaip noras išsiskirti ar pabrěžti savo unikalumą, santykị ir hierarchinę poziciją esamoje bendruomeneje.

5. Vartotojiškumas yra neribota veikla, todèl individai gali priklausyti kelioms ,gentims“ vienu metu, taip minimizuojant konkurencijos tarporganizacines įtampas. Tam įtakos turi ir tai, kad prekès ar paslaugos pasirenkamos, atsižvelgiant ne ị jų kokybės ir kainos santykį, o ị estetinę, emocinę dimensiją.

6. Siekiant organizacijoms tokią bendruomenę (gentị) suformuoti siūloma atsižvelgti ị šiuos aspektus: netikètas grupès atsiradimas ir ideologijos kūrimas, bendra grupès mitologija (tikèjimų visumą), ritualų būtinumas (jie turètų tapti tikẻjimų visumos išraiškos formomis), savita simbolika, kuri taptų narystė išraiškos instrumentu ir nuolat akcentuotų priklausymo ar nepriklausymo grupei aspektus, siekiant suskirstyti visuomenès narius ị savus ir svetimus.

Gauta 20141210

Pasirašyta spaudai 20150317

\section{Literatūra}

Bauman, Z. (2004). Work, Consumerism and the New Poor. Berkshire: McGraw-Hill Education.

Berger, A. A. (2011). Ads, Fads, and Consumer Culture: Advertising's Impact on American Character and Society. Blue Ridge Summit: Rowman \& Littlefield Publishers, Inc.

Boden, S. (2003). Consumerism, Romance and the Wedding Experience. Gordonsville: Palgrave Macmillan.

Burbach, R. (2001). Globalization and Postmodern Politics: From Zapatistas to Hihg Tech Robber Barons. London: Pluto Press.

Canniford, R. (2011). How to manage consumer tribes. Journal of Strategic Marketing 19(7): 591-606.

Cova, B., Cova, V. (2002). Tribal Marketing as the Tribalisation of Society and its Impact on the Conduct of Marketing. European Journal of Marketing, Vol. 36, Issue 5/6: 595-620.

Cova, B., Saucet, M. (2014). Unconventional Marketing: From Guerrila to Consumer made. - Routledge Companion on Future of Marketing, Part III. Reconnecting with Consumers and Markets, Forthcoming, San Diego Legal Studies, Paper No. 14: 165. 
Dionisio, P., Leal, C., Moutinho, L. (2000). Fandom affiliation and tribal behaviour: a sports marketing application. Qualitative Market Research: an International Journal, Vol. 11, Issue 1: 17-39.

Deutsch, B. (2011). Social Tribes. Sales \& Services Excellence, Vol. 11(4): 4

Dunn, R. G. (1998). Identity Crises: A Social Critique of Postmodernity. Minneapolis: University of Minnesota Press.

Francese, J. (1997). Narrating Postmodern Time and Space. New York: Albany State University Press.

Fromm, E. (2005). Turéti ar büti? Vilnius: Verba vera.

Fuat Firat, A., Clifford, J., Shultz, I. (1997). From Segmentation to Fragmentation. European Journal of Marketing, Vol. 31, Issue 3/4: 183-207.

Garry, T., Broderick, A. J., Lahiffe, K. (2008). Tribal Motivation in Sponsorship and its Influence on Sponsor Relationship Development and Corporate Identity. Journal of Marketing Management, Vol. 24(9-10): 959-977.

Gómez-Arias, J. T., Acebrón, L. B. (2001). Postmodern Approaches in Business - to Business Marketing and Marketing Research. Journal of Business and Industrial Marketing, Vol. 16, Issue 1, p. 7-20.

Goulding, C., Shankar, A., Canniford, R. (2013). Learning to be Tribal Facilitating the Formation of Consumer Tribes. European Journal of Marketing, Vol. 47, Issue 5/6: 813-832.

Hassan, I. (2001). The Postmodern Turn: Essays in Postmodern Theory and Culture. Christchurch: Cybereditions Corporation.

Hjorth, D., Kostera, M. (2007). Entrepeneurhsip and the Experience Economy. Frederiskberg Copenhagen: Copenhagen Business School Press.

King, C. S. (2005). Postmodern Public Administration: in the Shadow of Postmodernism. Administrative Theory and Praxis, Vol. 27.3: 517-532.

Lyotard, J. F. (1993). Postmodernus Būvis. Vilnius: Baltos lankos.

Meir, R., Scott, D. (2007). Tribalism: Definition, Identification and Relevance to Marketing of Professional Sports Franchises. International Journal of Sports Marketing and Sponsorship, Vol. 8(4): 330-346.

Mitchell, C., Imrie, B. C. (2011). Consumer Tribes: Membership, Consumption and Building Loyalty: Asia. Pacific Journal of Marketing and Logistics, Vol. 23, Issue 1: 39-56.

Murphy, J. W. (1989). Postmodern Social Analysis and Criticism. New York: Greenwood Press.

O'Shaughnessy, J., O'Shaughnessy, N. (2002). Marketing the Consumer Society and Hedonism. European Journal of Marketing, Vol. 36, Issue. 5/6: 524-547.

Patterson, M. (1998). Direct Marketing in Postmodernity: Neo-tribes and Direct Communications. Marketing Intelligence and Planing, Vol. 16, Issue 1: 68-74.

Payne, R. K. (2010). How Much is Enough?: Buddhism, Consumerism, and the Human Environment. Somerville: Wisdom Publications.

Rojek, C. (1995). Decentring Leisure: Rethinking Leisure Theory. London: SAGE Publications.

Simmons, G. (2008). Marketing to postmodern consumers: introducing the internet chameleon. European Journal of Marketing, Vol. 42, Issue 3/4: 299-310.

Veblen, T. (1899 [1994]). The Theory of the Leisure Class: an Economic Study of Institution. Mineota, N.Y.: Dover Publications.

\title{
POSTMODERNIST CONSUMERISM AS THE REASON FOR TRIBAL MARKETING FORMATION AND THE AIM FOR DEVELOPMENT
}

\author{
Adomas Vincas Rakšnys, Arvydas Guogis
}

\section{Summary}

In the article the contemporary postmodern consumerist societal characteristics are analyzed by revealing their life forms and thought trajectories. The private sec- 
tor, by managing to attract attention to the cultural changes, enables to formulate constructivist and profitable strategy of tribal marketing. The preconditions for the success of such strategy and the evolution of consumerism to its group like, "tribal" forms, arise from the reason of identities crisis in the society, communications development, values degradation, the diminishing of the family and religion roles and the refusal from future perspectives, which cause the absolutisizing of the moment and its experience intensity. By means of theoretical analysis the main merits of tribal marketing are revealed in the article as well as the good practise implementation examples and the psychological elements which are indispensable for that strategy in formation of the postmodernist epoch parameters. The main aspects which may be useful for private sectors organizations, which are seeking to get merits from application of tribal marketing, are to pay attention to long-term loyalty and return relations in evaluation of production. This aspect is becoming as more representative and advertising element, which helps to widen the circle of consumerist objects. But it is also important to understand that it is possible to orientate oneself to already existing community, for example, which connects around the concrete activities of sports team. In this case it is possible to use postmodernist instruments - symbols, simulations, massive attributes in order to focus attention to the arousal of consumerism in such communities. The orientation is attributed to such human factors as anxiety to be distinguished or stressing of Your uniquenessor hierarchical position in the given community. These factors are strengthened by the epochs consumerist imperative factors, when there appears the possibility to avoid social isolation by using different strategy of the cult of things or services. This phenomena forms the new dialogue forms which develop during the process of consumerism. In the "tribes", by consuming the same products, the satisfaction of oneself strengthens the emotions and at the same time develops the common group feelings. The attractiveness of tribal marketing is evident also because of not restricted consumerism activities, when the individuums may depend on several "tribes" at the same time. In this case the tensions of inter-organizational competition are minimized. It is note-worthy to understand that in postmodern society the products and services are chosen not according to their quality and price relation, but to an aesthetic and emotional dimension.

In now a days societies the new organizational forms develop, which mobilize individuals to form some kind of group identities by reaching consumers communities. Consumerism is the essential feature of such communities, which may be treated as certain "tribes" with their values and they develop as capitalist system develops in depth and width. Postmodernism creates such cultural environment, which forms "tribal marketing" as directing certain groups for the more developed, clearly defined and specific consumption. The authors in the article are revealing 
the influence of consumerism phenomena, as the one of postmodernist cultural parts, to the formation of "tribal marketing" and the development of this phenomena in the opposite direction. It is necessary for private sectors organizations, which are seeking to form postmodern consumerist community, to base oneself on such scientific discourse analysis which pays attention to unexpected appearance of the group and its ideology with common group mythology (complexity of beliefs), the necessity of rituals (which may become as the beliefs expression forms), original symbolics, which may become as the instrument for membership in order to accentuate constantly the dependence or not-dependence to the group and seeking to differentiate the members of society into "one's own" and "different" members. The focus of attention to these aspects in postmodern epoch may help private sectors organizations to maximize profits and succeed. 
